\title{
Upregulation of alpha cell glucagon-like peptide 1 (GLP-1) in Psammomys obesus - an adaptive response to hyperglycaemia?
}

\author{
A. M. K. Hansen • T. B. Bödvarsdottir • \\ D. N. E. Nordestgaard • R. S. Heller • C. F. Gotfredsen • \\ K. Maedler • J. J. Fels • J. J. Holst • A. E. Karlsen
}

Received: 21 October 2010 /Accepted: 21 December 2010/Published online: 25 February 2011

(C) Springer-Verlag 2011

\begin{abstract}
Aims/hypothesis The hormone glucagon-like peptide 1 (GLP-1) is released in response to a meal from the intestinal L-cells, where it is processed from proglucagon by the proconvertase (PC) $1 / 3$. In contrast, in the adult islets proglucagon is processed to glucagon by the PC2 enzyme. The aim of the study was to evaluate if, during the development of diabetes, alpha cells produce GLP-1 that, in turn, might trigger beta cell growth.

Methods Beta cell mass, GLP-1 and insulin levels were measured in the gerbil Psammomys obesus (P. obesus), a rodent model of nutritionally induced diabetes. Furthermore, the presence of biologically active forms of GLP-1 and $\mathrm{PC} 1 / 3$ in alpha cells was demonstrated by immunoflu-
\end{abstract}

A. M. K. Hansen and T. B. Bödvarsdottir are joint first authors.

Electronic supplementary material The online version of this article (doi:10.1007/s00125-011-2080-1) contains supplementary material, which is available to authorised users.

A. M. K. Hansen · T. B. Bödvarsdottir · C. F. Gotfredsen •

J. J. Fels

Diabetes Research Unit, Novo Nordisk A/S,

Måløv, Denmark

D. N. E. Nordestgaard • R. S. Heller • A. E. Karlsen ( $\bowtie)$

Hagedorn Research Institute,

Niels Steensensvej 1,

2820, Gentofte, Denmark

e-mail: AEK@novonordisk.com

K. Maedler

Centre for Biomolecular Interactions, Universität Bremen,

Bremen, Germany

J. J. Holst

Faculty of Health Sciences, Department of Medical Physiology,

København, Denmark orescence, and the release of GLP-1 from isolated $P$. obesus, mouse and human islets was investigated.

Results During the development of diabetes in P. obesus, a significant increase in GLP-1 was detected in the portal vein $(9.8 \pm 1.5$ vs $4.3 \pm 0.7 \mathrm{pmol} / 1, p<0.05)$, and in pancreas extracts $(11.4 \pm 2.2$ vs $5.1 \pm 1.3 \mathrm{pmol} / \mathrm{g}$ tissue, $p<0.05)$. Freshly isolated islets from hyperglycaemic animals released more GLP-1 following $24 \mathrm{~h}$ culture than islets from control animals $(28.2 \pm 4.4 \mathrm{pmol} / \mathrm{l}$ vs $5.8 \pm 2.4, p<0.01)$. GLP-1 release was increased from healthy $P$. obesus islets following culture in high glucose for 6 days $(91 \pm 9.1 \mathrm{pmol} /$ 1 vs $28.8 \pm 6.6, p<0.01$ ). High levels of GLP-1 were also found to be released from human islets. $\mathrm{PC} 1 / 3$ colocalised weakly with alpha cells.

Conclusions/interpretation GLP-1 release from alpha cells is upregulated in P. obesus during the development of diabetes. A similar response is seen in islets exposed to high glucose, which supports the hypothesis that GLP-1 released from alpha cells promotes an increase in beta cell mass and function during metabolic challenge such as diabetes.

Keywords GLP-1 1 Islet $\cdot$ P. obesus

$\begin{array}{ll}\text { Abbreviations } \\ \text { BCM } & \text { Beta cell mass } \\ \text { BHK } & \text { Baby hamster kidney } \\ \text { DPP-IV } & \text { Dipeptidyl peptidase } 4 \\ \text { GLP-1 } & \text { Glucagon-like peptide-1 } \\ \text { GSIS } & \text { Glucose-stimulated insulin secretion } \\ \text { HED } & \text { High-energy diet } \\ \text { LE } & \text { Low-energy chow } \\ \text { LOCI } & \text { Luminescence oxygen channelling } \\ & \text { immunoassay }\end{array}$


$\mathrm{mAb} \quad$ Monoclonal antibody

mBG Morning blood glucose

$\mathrm{PC} \quad$ Prohormone convertase

$\mathrm{P} / \mathrm{S} \quad$ Penicillin/streptomycin

\section{Introduction}

Conventional treatment of type 2 diabetes aims to control blood glucose levels through diet and exercise, drugs that target insulin secretion or resistance or by insulin injections. Despite intensive intervention therapies, the diabetic patient displays a continued decline in beta cell mass (BCM) and function [1]. The incretin hormone glucagon-like peptide (GLP)-1 is currently receiving considerable interest because of its ability not only to reduce blood glucose levels but also to potentially regenerate islet BCM [2]. Several in vitro [3, 4] and rodent in vivo studies [5-7] have demonstrated antiapoptotic and proliferative effects of GLP-1 on pancreatic beta cells. Clearly, restoration of beta cell function will be of a great therapeutic value in the treatment of diabetes.

GLP-1 is a product of the pro-glucagon gene. The proglucagon precursor hormone is produced in intestinal L-cells, pancreatic alpha cells and a subset of neurons. The presence of different processing enzymes allows cell-specific products to be generated from the same precursor. In the L-cells, prohormone convertase (PC) $1 / 3$ is responsible for the generation of GLP-1 and GLP-2, whereas the alpha cells produce glucagon as a result of processing by PC 2 , leaving the active form of the GLP-1 peptide trapped in a larger fragment, the major proglucagon fragment $[8,9]$. After GLP1 is released from the intestinal L-cells to the circulation, it is very rapidly degraded to an inactive metabolite (GLP-1 [937]) by the enzyme dipeptidyl peptidase 4 (DPP-IV) and only a small fraction reaches the pancreatic beta cells that express the GLP-1 receptor $[10,11]$

The prevailing view is that in adults, all circulating GLP1 is produced by the intestinal L-cells, with no contribution from the alpha cells as they are thought not to produce PC1/3, thus excluding GLP-1 production. However, several reports have demonstrated the production of a small amount of fully processed GLP-1 from alpha cells [12-15]. Furthermore, during specific stages of fetal development glucagon-positive cells in the pancreas co-produce $\mathrm{PC} 1 / 3$ and hence potentially also secrete GLP-1, which may be of importance during islet cell differentiation [16, 17]. These findings raise the possibility that GLP-1, produced within the islets under certain circumstances, acts as a paracrine factor facilitating beta cell protection and function as well as regeneration when needed. The alpha cells are in close proximity to the GLP-1 receptors on the beta cells, and alpha cells may, if GLP-1 production is switched on, provide a continuous beneficial supply of GLP-1 to the neighbouring beta cells. In support of this view it has recently been shown that rats with streptozotocin-induced beta cell loss display increased islet GLP-1 production [18, 19]. Recently it was elegantly shown by adenovirus introduction of $\mathrm{PC} 1 / 3$ in islet glucagon cells that GLP-1 can be released and act locally to improve islet function [15].

The gerbil Psammomys obesus is an animal model of nutritionally induced type 2 diabetes [20-22]. When these animals are transferred from their natural low-energy saltbush diet to more energy-dense rodent laboratory chow, the initial response is an increase in BCM to compensate for the increased insulin demand, followed by development of hyperglycaemia. This animal model is characterised by fast depletion of insulin stores as hyperglycaemia becomes manifest $[23,24]$. Not all animals become hyperglycaemic as some are resistant to the high-energy diet and stay normoglycaemic (non-responders). In this paper, we used $P$. obesus to investigate the hypothesis that production of GLP1 within the islets serves as a natural mechanism employed by the islets to promote beta cell function and increase BCM under situations of sustained metabolic pressure, such as hyperglycaemia. The findings are supported by in vitro studies using isolated $P$. obesus, human and mouse islets.

\section{Methods}

Animals Male and female P. obesus, aged 7-9 weeks (Harlan, Jerusalem, Israel) were fed low-energy chow (LE $10 \mathrm{~kJ} / \mathrm{g}$ ) until the age of 14-15 weeks, when all animals except for an 'LE' group, were transferred to an ad libitum high-energy diet (HED $13 \mathrm{~kJ} / \mathrm{g}$ ). Body weight (BW), morning blood glucose $(\mathrm{mBG})$ and $\mathrm{HbA}_{1 \mathrm{c}}$ were measured once weekly. After 4-5 weeks, animals were killed and based on $\mathrm{mBG}$ the animals were categorised as responders $(\mathrm{mBG} \geq 10 \mathrm{mmol} / \mathrm{l})$ or non-responders $(\mathrm{mBG}<10 \mathrm{mmol} / \mathrm{l})$. This experimental protocol was repeated in order to obtain pancreases for characterisation of insulin content and BCM as described below. The study was approved by the Animal Experiments Inspectorate, Ministry of Justice, Denmark.

$m B G$ Blood samples were collected from the tail and $\mathrm{mBG}$ was measured as previously described by Vedtofte et al. [25].

Measurement of insulin and GLP-1 in P. obesus plasma Blood was collected from the aorta and vena porta when the animals were killed and the plasma was stored at $-80^{\circ} \mathrm{C}$ until analysis of insulin and GLP-1 was carried out.

Detection of insulin was by luminescence oxygen channelling immunoassay (LOCI) using two monoclonal antibodies (mAbs; mAb HUI-018 and mAb OXI005-03B) that recognise two different epitopes. The principle of the LOCI method is described in the electronic supplementary material (ESM). 
Intact GLP-1 was detected with a method similar to that carried out for insulin determination by LOCI. However, two different mAbs were used: acceptor beads were conjugated with $\mathrm{mAbF} 5$ (which recognises amino acids 25-33 of GLP-1 [7-37]) and for biotinylation, mAb26.1 (which recognises amino acids 7-8 of GLP-1 [7-37]).

Measurements of GLP-1 and insulin in culture medium or $K R B$ GLP-1 from $P$. obesus islets in culture medium and GLP-1 from mouse and human islets in KRB were measured as described above, with the difference that the calibrators and controls were prepared in the corresponding matrix. Human insulin levels in KRB were measured by LOCI as described above with the following modifications: acceptor beads were conjugated with mAb RDI-TRK2IP10D6C4, and mAb RDI-TRK2IP10-D3E7 was used for biotinylation. Calibrators and controls were prepared in the corresponding matrix.

\section{Measurement of pancreatic GLP-1 and insulin content in P.} obesus Pancreases were removed from a subset of animals, weighed and immediately frozen in liquid nitrogen. For peptide extraction the tissue was dissolved in 1\% (vol./vol.) trifluoroacetic acid and peptide material was isolated from using Sep-Pak C18 cartridges (Waters, Milford, MA, USA). Bound material was eluted with 70\% (vol./vol.) ethanol and $0.1 \%$ (vol./vol.) trifluoroacetic acid, and lyophilised. Lyophilised material was dissolved phosphate buffered saline (+ albumin $0.1 \%$ [wt/vol.]) and the content of GLP1 and insulin was measured by radioimmunoassay. Carboxy-terminal GLP-1 immunoreactivity was determined using antiserum 89390 [26], which has an absolute requirement for the intact amidated carboxy terminus of GLP-1 7-36 amide and has cross-reactivity of less than $0.01 \%$ with fragments truncated at the carboxy terminus and 89\% with GLP-1 9-36 amide, the primary metabolite of DPP4-mediated degradation. Sensitivity was below $5 \mathrm{pmol} / 1$, and the intra-assay coefficient of variation was below $10 \%$ [26]. Insulin was measured as previously described by Brand et al. [27].

cAMP measurements Cells were harvested from a stable transfected baby hamster kidney (BHK) cell line producing the human GLP-1 receptor or the human glucagon receptor, and were stimulated with GLP-1, glucagon or islet culture medium. The response of GLP-1-, glucagon- or islet-mediuminduced cAMP production was monitored using the FlashPlate Assay from PerkinElmer (Skovlunde, Denmark). The basic principle of the FlashPlate Assay is a competition between radioactive and non-radioactive cAMP for a fixed number of binding sites. Islet medium was incubated overnight at $4^{\circ} \mathrm{C}$ with or without a high-affinity glucagon mAb [27] or GLP-1 $\mathrm{mAb}$ (Mab26.1) prior to the cAMP assay.
Islet isolation Islets were isolated from mice and $P$. obesus as described in the ESM. Human islets were obtained from Prodo Laboratories (Irvine, CA, USA). From one donor, a 43-year-old man, the islet purity was $75 \%$ and islet viability was $85 \%$. From another donor, a 60 -year-old man, the islet purity was $70 \%$ and islet viability was $95 \%$. The study conformed to the ethical guidelines of Novo Nordisk for the use of human biological material. At arrival the islets were incubated free-floating in Petri dishes in RPMI 1640 medium (5.5 mmol/l glucose) supplemented with 5\% (vol./vol.) human serum (Lonza, Basel, Switzerland) and 1\% (vol./ vol.) penicillin/streptomycin $(\mathrm{P} / \mathrm{S})$ and the perifusion experiment was performed the day after arrival.

In vitro islet studies Freshly isolated P. obesus islets were handpicked and incubated in extracellular-matrix-coated 96 well plates (Biological Industries, Kibbutz Beit Haemek, Israel) with 10-15 islets/well in $150 \mu \mathrm{l}$ RPMI 1640 (Invitrogen, Carlsbad, California) supplemented with $1 \%$ (vol/vol) penicillin/streptomycin, 10\% (vol/vol) newborn calf serum and D-glucose at varying concentrations. The islets were incubated in a $5 \% \mathrm{CO}_{2}$ humidified atmosphere at $37^{\circ} \mathrm{C}$. After incubation the buffer was carefully removed from the islets and filtered through a 96 well filter plate (Multiscreen-DV from Millipore, Billerica, MA, USA) and stored at $-20^{\circ} \mathrm{C}$ until analysis.

Mouse and human islets were placed in 96 well plates with 25 islets per well. The mouse islets were placed in the same medium as the P. obesus islets. Human islets were placed in RPMI 1640 (5.5 mmol/ 1 glucose) supplemented with 5\% (vol./vol.) human serum (Lonza) and 1\% (vol./vol.) P/S. After 3 days, the islets were washed and incubated with $200 \mu \mathrm{KRB}$ (115 mmol/ $1 \mathrm{NaCl}, 4.7 \mathrm{mmol} / 1 \mathrm{KCl}, 2.6 \mathrm{mmol} / 1 \mathrm{CaCl}_{2}, 1.2 \mathrm{mmol} /$ $1 \mathrm{KH}_{2} \mathrm{PO}_{4}, 1.2 \mathrm{mmol} / 1 \mathrm{MgSO}_{4}, 10 \mathrm{mmol} / \mathrm{l} \mathrm{HEPES}, 0.2 \%$ (wt/vol.) BSA, $2 \mathrm{mmol} / \mathrm{l}$ glutamine, $5 \mathrm{mmol} / 1 \mathrm{NaHCO}_{3}$, $1 \%$ (vol./vol.) $\mathrm{P} / \mathrm{S}, \mathrm{pH} 7.4$ ) for $1 \mathrm{~h}$. After incubation the buffer was carefully removed from the islets and filtered through a 96-well filter plate and stored at $-20^{\circ} \mathrm{C}$ until analysis.

Islet perifusion Islets were washed in KRB and subsequently used in an islet perifusion experiment (Suprafusion 2500, Brandel, Lynge, Denmark). Four columns each with 40 islets were used. The islets were placed in Bio-gel P2 (BioRad, Copenhagen, Denmark) in the columns with a nylon mesh below and above the gel. The islets were initially perifused for $40 \mathrm{~min}$ with $\mathrm{KRB}$ containing $3 \mathrm{mmol} / 1$ glucose to obtain a stable baseline of insulin release. After 40 min the buffer was exchanged with $15 \mathrm{mmol} / 1$ glucose $\pm 0.5 \mu \mathrm{mol} / 1$ exendin (939) for $70 \mathrm{~min}(40-110 \mathrm{~min})$. Finally, the buffer was exchanged to low glucose $(3 \mathrm{mmol} / \mathrm{l})$ for $30 \mathrm{~min}(110$ 
$140 \mathrm{~min}$ ). The buffer was set to flow through the perifusion system at a rate of $0.3 \mathrm{ml} / \mathrm{min}$. Samples were taken every $5 \mathrm{~min}$ from time 30 to $140 \mathrm{~min}$. Samples were stored at $-20^{\circ} \mathrm{C}$ and subsequently analysed for insulin.

Immunohistochemistry Human pancreatic sections from weight- and age-matched healthy controls and from patients with type 2 diabetes ( $n=7$, respectively) were obtained from the National Disease Research Interchange. The method for staining the pancreas sections is described in the ESM.

Pancreas morphometry The pancreases of a subset of the animals were examined histologically, as previously described by Raun et al. [28]. Briefly, pancreases were fixed in paraformaldehyde and sectioned according to a design-based stereological sampling scheme, the smooth fractionator method [29]. The sections were stained for insulin to visualise beta cells. BCM was evaluated stereologically in two to three sections with the origin of the sections blinded to the observer. The insulin staining intensity was graded semi-quantitatively on a scale of $0-5$, with 0 being equal to islets characterised by absence of insulin staining and 5 equalling islets with insulin staining as seen in LE-fed P. obesus and in normal rat pancreas. The grading was carried out with the origin of the sections blinded to the observer.

Statistical methods All data are expressed as mean \pm SEM. Student's $t$ test was used for comparison of two groups. A value of $p<0.05$ was considered statistically significant.

\section{Results}

Development of hyperglycaemia in HED-fed P. obesus When transferred to the HED, about two-thirds of the animals $(n=26)$ became hyperglycaemic $(\mathrm{mBG} 15.5 \pm$ $0.7 \mathrm{mmol} / \mathrm{l})$ after 4 weeks. One-third of the animals $(n=$
15) were resistant to the HED and stayed normoglycaemic (mBG $5.7 \pm 0.8$ mmol/l; Fig. 1a).

$B C M$, insulin staining intensity, and insulin and GLP-1 content of P. obesus pancreases at death After 4 weeks of HED, BCM was increased in responders $(70 \pm 9 \mathrm{mg} / \mathrm{kg}, n=$ $26, p<0.05)$ and non-responders $(87 \pm 10 \mathrm{mg} / \mathrm{kg}, n=19, p<$ $0.01)$, compared with animals on the LE diet $(35 \pm 7 \mathrm{mg} / \mathrm{kg}$, $n=10$; Fig. 1b). The intensity of the insulin staining decreased in the hyperglycaemic responders $(1.1 \pm 0.1, p<$ $0.001)$ and non-responders $(2.6 \pm 0.3, p<0.001)$, as compared with LE-fed animals (5.0 \pm 0.0 ; Fig. 1c). Pancreatic insulin content was higher in the non-responders compared with the hyperglycaemic animals $(3.4 \pm 0.5 \mathrm{nmol} / \mathrm{g}$ tissue $[n=9]$ vs $1.4 \pm 0.3 \mathrm{nmol} / \mathrm{g}$ tissue $[n=16], p<0.01)$ but was not significantly different from the LE group $(2.1 \pm$ $0.2 \mathrm{nmol} / \mathrm{g}$ tissue [ $n=6]$; Fig. 2a).

Portal vein levels of insulin were significantly higher in both the hyperglycaemic animals $(5.5 \pm 0.6 \mathrm{nmol} / 1[n=19]$, $p<0.001)$ and in the non-responders $(5.7 \pm 0.9 \mathrm{nmol} / 1[n=$ $10], p<0.001)$ compared with control LE animals $(0.2 \pm$ $0.05 \mathrm{nmol} / \mathrm{l}[n=9]$; Fig. 2b).

Analysis of the level of amidated GLP-1 in pancreatic extracts revealed a significant increase in the hyperglycaemic animals after 4 weeks on HED compared with LE-fed control animals $(11.4 \pm 2.2 \mathrm{pmol} / \mathrm{g}$ tissue $[n=9]$ vs $5.1 \pm$ $1.3 \mathrm{pmol} / \mathrm{g}$ tissue $[n=9], p<0.05$; Fig. $2 \mathrm{c}$ ). The pancreas content of intact GLP-1 in the non-responders was not significantly different from the LE controls $(4.6 \pm 1.1 \mathrm{pmol} / \mathrm{g}$ tissue $[n=7])$. The increased GLP-1 level in the pancreases of hyperglycaemic animals was reflected in the portal vein plasma concentration, for which intact GLP-1 was also significantly higher in the hyperglycaemic group $(9.8 \pm$ $1.5 \mathrm{pmol} / \mathrm{l}, p<0.05[n=30])$ compared with the LE control group ( $4.3 \pm 0.3 \mathrm{pmol} / 1[n=14])$, while GLP-1 levels in the non-responders $(5.4 \pm 0.8 \mathrm{pmol} / 1[n=20])$ were not different from LE controls (Fig. 2d). In contrast, for all animal groups plasma levels of intact GLP-1 in the aorta were below or
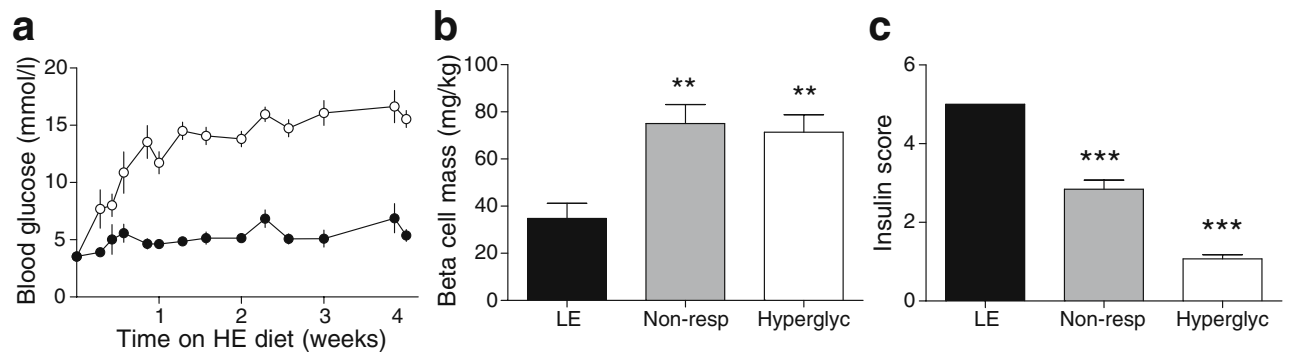

Fig. 1 Diabetes development in P. obesus. a Blood glucose in $P$. obesus on the HED. Responders (white circles; $n=26$ ); nonresponders (black circles; $n=15$ ). b BCM in P. obesus after 4 weeks on the HED: non-responder, $n=19$; hyperglycaemic, $n=26$. Values for

LE-fed controls $(n=10)$ are also shown. Non-resp, non-responder; hyperglyc, hyperglycaemic. $*^{*} p<0.01$ compared with control. c Insulin score for the same animals as in $\mathbf{b}$. $* * * p<0.001$ compared with control 
a

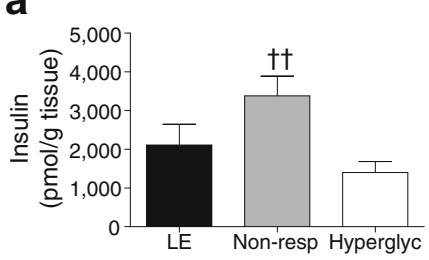

C

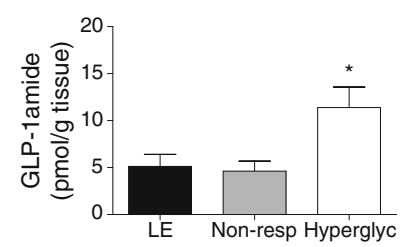

b
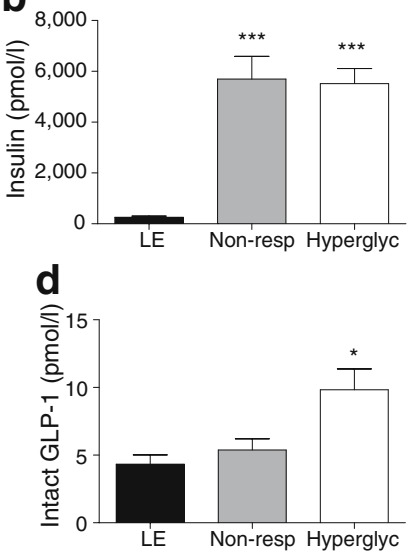

Fig. 2 P. obesus plasma levels and pancreas content of insulin and active GLP-1 (a,c) Pancreas content of (a) insulin LE-fed control animals $(n=6)$, non-responders $(n=9)$ and hyperglycaemic $(n=16)$ animals and (c) GLP-1 amide of LE-fed control animals $(n=9)$, nonresponders $(n=7)$ and hyperglycaemic $(n=9)$ animals.(b, d) Vena porta plasma levels of $(\mathbf{b})$ insulin LE-fed control animals $(n=9)$, nonresponders $(n=10)$ and hyperglycaemic $(n=19)$ animals and $(\mathbf{d})$ intact GLP-1 from $P$. obesus after 4 weeks on the HED (non-responder, $n=$ 20; hyperglycaemic, $n=30$ ) or LE diet (control, $n=14$ ). Non-resp, nonresponder; hyperglyc, hyperglycaemic. ${ }^{*} p<0.05$; ${ }^{* * *} p<0.001$ compared with control. ${ }^{\dagger} p<0.01$ relative to hyperglycaemic animals

only slightly above the quantification limit of the assay (0.7 pmol/l; data not shown).

GLP-1 release from $P$. obesus islets To characterise the GLP-1 release further, accumulated GLP-1 release was analysed over $24 \mathrm{~h}$ in freshly isolated islets. Islets from hyperglycaemic animals released significantly more GLP-1 than islets from control animals $(28.2 \pm 4.4 \mathrm{pmol} / 1$ vs $5.8 \pm$ 2.4, $p<0.01$; Fig. 3a).

Glucose-induced GLP-1 release from P. obesus islets As diabetes is characterised by hyperglycaemia, we investigated if GLP-1 production by $P$. obesus islets could be increased by chronically elevated glucose levels in vitro. Incubation of control islets, isolated from P. obesus on the LE diet, for $24 \mathrm{~h}$ in 3,12 or $25 \mathrm{mmol} / \mathrm{l}$ glucose did not lead to glucosedependent changes in GLP-1 release (Fig. 3b). However, after 6 days of incubation a significant dose-dependent increase in GLP-1 release during the last $24 \mathrm{~h}$ of the 6 day culture period was observed $(29 \pm 7 ; 60 \pm 6[p<0.05]$ and $91 \pm 9 \mathrm{pmol} / 1[p<$ $0.01]$ for 3,12 and $25 \mathrm{mmol} / 1$ glucose, respectively $[n=3]$; Fig. 3b).

GLP-1 release from human and mouse islets To establish if GLP-1 release could also be induced in human islets, isolated islets (pre-cultured in medium containing $5.5 \mathrm{mmol} / 1$ glucose for 3 days) were incubated for $1 \mathrm{~h}$ in KRB. A considerable amount of GLP-1 $\left(72 \pm 3 \mathrm{fmol}\right.$ islet $\left.^{-1} / \mathrm{h}^{-1} \times 100[n=4]\right)$ was measured, whereas the release from mouse islets was very low

$\left(3.0 \pm 2.5 \mathrm{fmol}\right.$ islet $^{-1} / \mathrm{h}^{-1} \times 100[n=3]$; Fig. 4a). The functional significance of the GLP-1 released from human islets was assessed in an islet perifusion experiment. Addition of the GLP-1 receptor antagonist exendin (9-39) markedly (54\%) reduced the glucose-stimulated insulin secretion (GSIS) in these islets (insulin AUC $30 \pm 9$ vs $65 \pm 4 \mathrm{ng} / 100$ islets, $p<$ 0.05 ; Fig. $4 b, c)$. Data are shown from one experiment out of two experiments from two donors yielding similar results ( $52 \%$ reduction for donor two). The results indicate that the GLP-1 receptor is active in these islets.

Bioactivity of GLP-1 released from P. obesus islets Next we evaluated the bioactivity of the GLP-1 released from the $P$. obesus islets. Incubation of GLP-1 receptorproducing $\mathrm{BHK}$ cells with supernatant fraction from $P$. obesus islets cultured for 4 days in $25 \mathrm{mmol} / 1$ glucoseactivated cAMP production to the same level as treatment of the cells with $100 \mathrm{pmol} / 1$ synthetic GLP-1 peptide (Fig. 5a). This receptor activation was, to a large extent, blocked by prior incubation of the islet medium with an antibody directed to the $\mathrm{NH}_{2}$-terminus of GLP-1 (mAb26.1; Fig. 5a). It is known that glucagon can activate the GLP-1 receptor with low potency $\left(\mathrm{EC}_{50} \approx 1 \mathrm{nmol} / \mathrm{l}\right)$ [30]. Islet culture supernatant fractions contain glucagon released from alpha cells that could be responsible for activation of the GLP-1 receptor in this assay. In order to demonstrate that active GLP-1 and not glucagon was responsible for the production of cAMP, the GLP-1 receptor activation experiment was also performed in the presence of a high-affinity glucagon mAb [27]. The highaffinity glucagon $\mathrm{mAb}$ had no effect on the GLP-1 receptor activation by the islet medium (Fig. 5a). It did, however, completely inhibit the glucagon receptor activation (Fig. 5b). Addition of islet supernatant fraction to
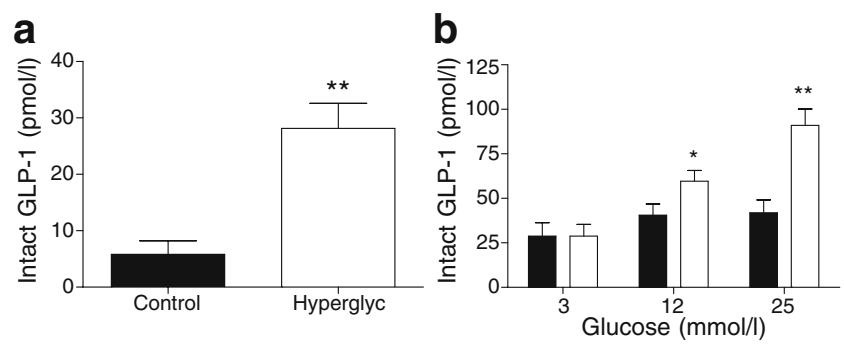

Fig. 3 Release of intact GLP-1 from P. obesus islets in vitro. a Release of intact GLP-1 from freshly isolated P. obesus islets from control animals on the LE diet and from hyperglycaemic (hyperglyc) animals on HED over a $24 \mathrm{~h}$ incubation. Data represent islets isolated from four control animals and from six hyperglycaemic animals. b Glucose-induced release of GLP-1 from islets from P. obesus on the LE diet cultured for $24 \mathrm{~h}$ (black bars) or 6 days (white bars) at 3, 12 or $25 \mathrm{mmol} / \mathrm{l}$ glucose. Medium accumulated over $24 \mathrm{~h}$; for the 6 day incubation the medium was changed between days 5 and 6 . Data are mean \pm SEM of three independent experiments. ${ }^{*} p<0.05 ; * * p<0.01$ compared with control 

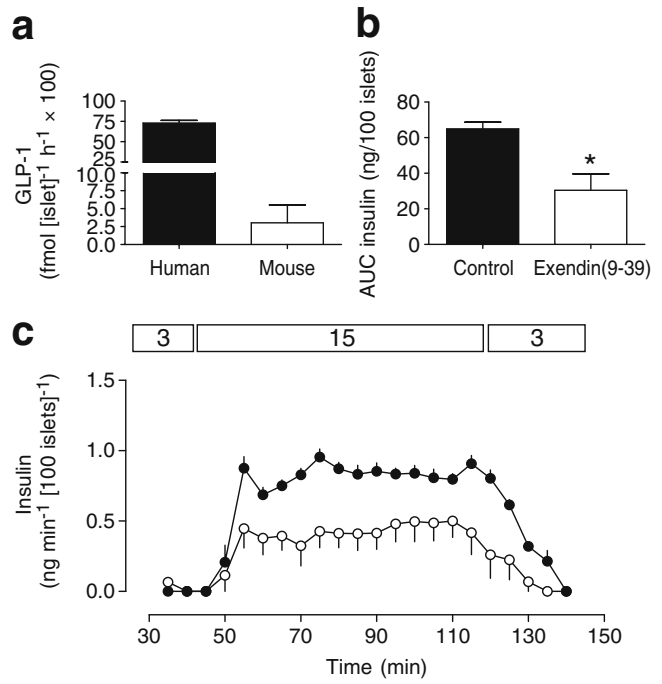

Fig. 4 GLP-1 release from mouse and human islets. a Intact GLP-1 released into $\mathrm{KRB}$ in a $1 \mathrm{~h}$ incubation (human data are mean $\pm \mathrm{SEM}$ of four independent experiments representing four donors). Mouse islets, $n=3$. b Total insulin secreted (insulin AUC) in perifusion experiment shown in c. c Islet perifusion experiment on human islets. Effect of GLP-1 receptor antagonist exendin (9-39) on GSIS. Black circles, glucose at: (1) $3 \mathrm{mmol} / \mathrm{l}$; (2) $15 \mathrm{mmol} / \mathrm{l}$; and (3) $3 \mathrm{mmol} / 1$. White circles, glucose at: (1) $3 \mathrm{mmol} / \mathrm{l}$; (2) $15 \mathrm{mmol} / 1+$ exendin (9-39); and (3) $3 \mathrm{mmol} / \mathrm{l}$. Data in $\mathbf{b}$ and $\mathbf{c}$ are from an experiment using islets from one donor with each condition run in quadruplicate (represented by error bars). The experiment was repeated on islets from a second donor, yielding similar results

non-transfected BHK cells resulted in no induction of cAMP production (Fig. 5c). This confirmed that GLP-1 released from the islets is an active form of the peptide.

Expression of GLP-1 in the pancreas Using antisera specific to the N-terminus of the active form of GLP-1 as well as antisera specific for the 7-36 amide form of the GLP-1 peptide, we performed immunocytochemistry to examine the localisation of GLP-1 in the islets. In most glucagon immunoreactive cells, both the C-terminal (amidated) and the N-terminal immunoreactivity of GLP1 were detectable in control and hyperglycaemic $P$. obesus (Fig. 6a, b) and the merge is shown by a pinkish colour. There was no colocalisation of GLP-1 amide and insulin. Also in human pancreas, there was a strong colocalisation of GLP-1 amide, N-terminally derived biologically active GLP-1 and glucagon in sections from both controls and patients with type 2 diabetes and no colocalisation with insulin (Fig. 6c, d).

$P C 2$ and $P C 1 / 3$ are produced in alpha cells of hyperglycaemic $P$. obesus and of patients with type 2 diabetes To further explore the production of GLP-1 in the islets and to establish whether changes in the processing enzymes responsible for processing proglucagon to glucagon (PC2) or GLP-1 (PC1/3) were changed in hyperglycaemic vs control islets from $P$. obesus as well as in islets from humans, histochemical analyses were performed. Pancreas sections from $P$. obesus and humans were stained for insulin, glucagon and $\mathrm{PC} 1 / 3$. The beta cells stained strongly for $\mathrm{PC} 1 / 3$ while the majority of alpha cells were weakly positive for $\mathrm{PC} 1 / 3$, and the surrounding exocrine pancreas showed no immunoreactivity (Fig. 6e-h). As seen in Fig. 6f, h the diabetic state results in a very different staining pattern. In hyperglycaemic $P$. obesus, nearly all the alpha cells now stained more intensely for PC1/3 (Fig. 6f) and some beta cells lost immunoreactivity. In sections from humans with type 2 diabetes, either a low level was observed, but not in every glucagon immunoreactive cell, or the staining was not much different from the nondiabetic state (Fig. 6g, h).

PC2 staining (co-staining with glucagon and insulin) of human and P. obesus normal and diabetic pancreas tissue is shown in ESM Fig. 1. In LE-fed P. obesus pancreas, PC2 was colocalised with both insulin and glucagon, while in the hyperglycaemic state, PC2 was only found in the alpha cells. This contrasts with the human pancreas, where PC2 was found in both insulin and glucagon cells in pancreases from control and type 2 diabetes patients.

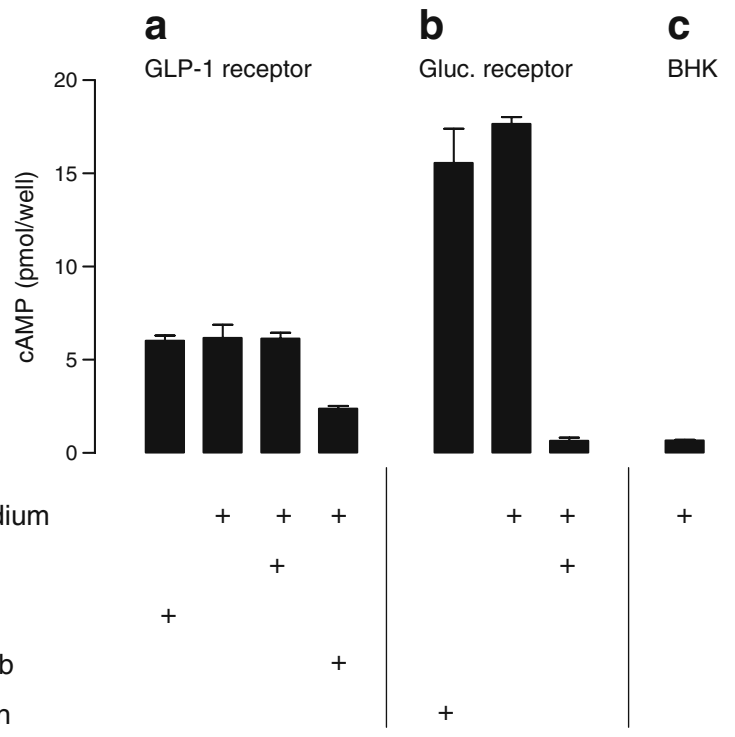

Glucagon

Fig. 5 Bioactivity of GLP-1 released by islets into medium. a cAMP production by activation of the GLP-1 receptor expressed in BHK cells by islet medium with and without pre-incubation with glucagon antibody or GLP-1 antibody; $100 \mathrm{pmol} / 1$ GLP-1 serves as positive control $\mathbf{b}$ cAMP production by activation of the glucagon receptor produced in BHK cells by islet medium with and without preincubation with glucagon antibody; $100 \mathrm{pmol} / 1$ glucagon serves as positive control. c cAMP production by non-transfected BHK cells stimulated with islet medium. The data shown are mean \pm SEM from a single representative experiment performed in duplicate. Glu Ab, high-affinity glucagon antibody 
Fig. 6 Pattern of glucagon, insulin and $\mathrm{PC} 1 / 3$ - and biologically active forms of GLP-1 in pancreas. a-d Colocalisation of glucagon with GLP-1 amide (a, c) and N-terminal GLP-1 (b, d) in normal and hyperglycaemic $P$. obesus and human pancreas. Nearly all glucagon cells are co-immunoreactive as denoted by a pink-purple colour. e-h Colocalisation of $\mathrm{PC} 1 / 3$ in insulin and some glucagon immunoreactive cells in normal and diabetic $P$. obesus and human pancreas. The white arrow marks glucagon-positive cells producing $\mathrm{PC} 1 / 3$. Scale bars $20 \mu \mathrm{m}$. N-Term, N-terminal
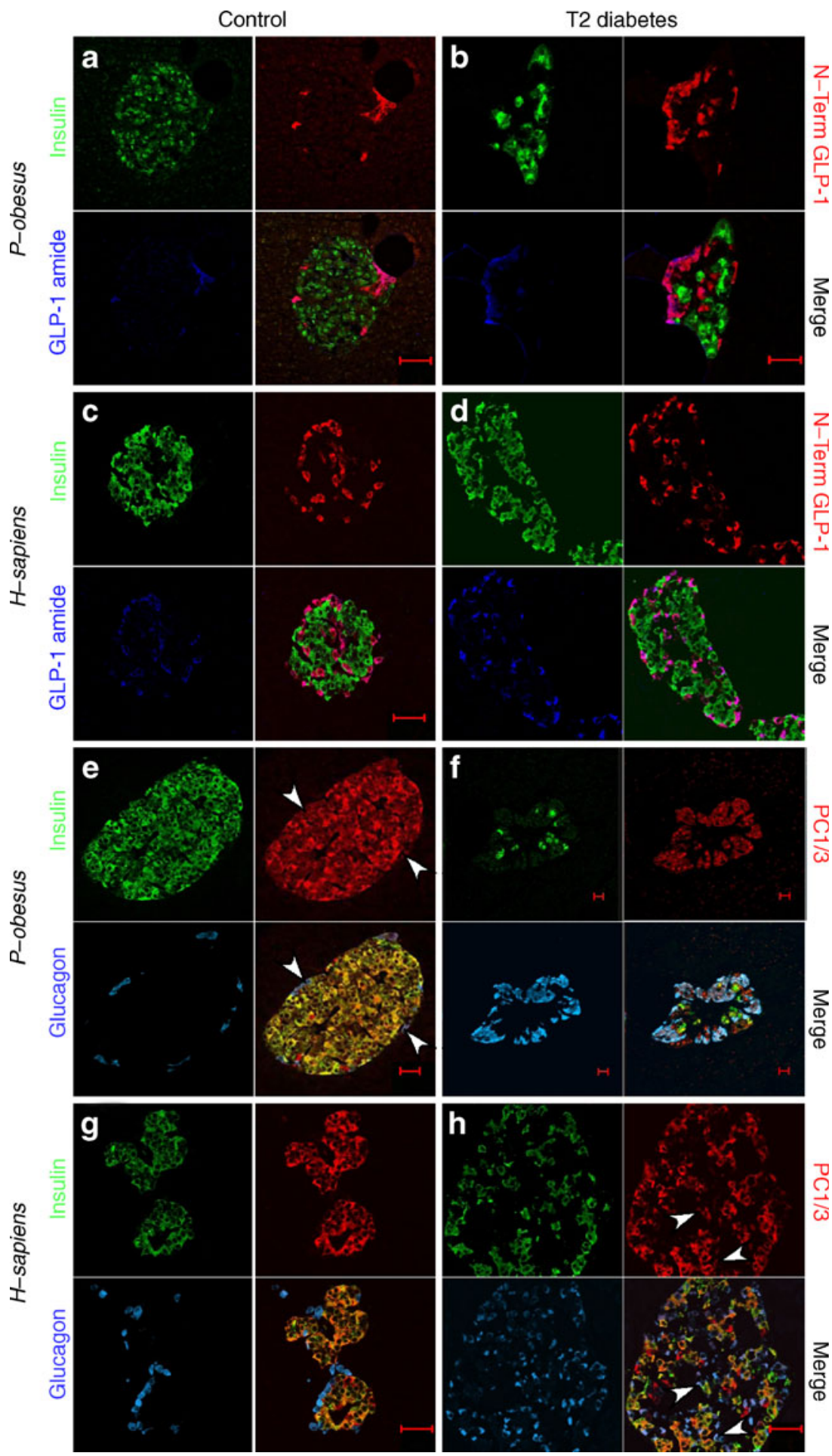

\section{Discussion}

We have provided evidence that pancreatic islets from $P$. obesus produce fully processed GLP-1 during the development of hyperglycaemia and that this production can also be induced in vitro following culture of $P$. obesus islets in high glucose. Pancreatic alpha cells from patients with type 2 diabetes and P. obesus stained positive for GLP-1, and human islets released GLP-1 in vitro. Based on our observations we hypothesise that this paracrine GLP-1 system may play a role in adult islets in regulating BCM and function when metabolic stress is imposed on the beta cells e.g. during the development of diabetes.

The pancreatic beta cells are located quite distantly from the GLP-1 producing L-cells in the intestine. It is well established that only a fraction of the intestinal GLP-1 
reaches the beta cell via the circulation because GLP-1 is exposed to inactivation by DPP-IV immediately after its release $[10,11]$. Bearing in mind this rapid decline in the peripheral GLP-1 signal arising from the L-cells, it is tempting to hypothesise the existence of a local GLP-1 signalling system in the islets close to the beta cell GLP-1 receptors. Indeed, proglucagon and $\mathrm{PC} 1 / 3$ colocalise in the pancreas at certain fetal stages, suggesting an important and transient role of GLP-1 during pancreas development [16, 18]. In the present study, we have shown also that the adult islet harbours a local GLP-1 signalling system, as has also been suggested by other studies [13]. Interestingly, a paracrine system involving GLP-1 was recently reported where GLP-1 produced locally by taste cells and acting via GLP-1 receptors produced on nearby afferent nerve fibres, serves to modulate taste sensitivity [31]. To what extent GLP-1 produced by the alpha cells will reach the beta cells is controversial, based on the proposed circulation from beta to alpha cells [32]. Nevertheless, it has recently been shown that islets in which $\mathrm{PC} 1 / 3$ production is enhanced by gene transfer display improved GSIS and are less sensitive to cytokine treatment. When transplanted to a mouse model of type 1 diabetes the GLP-1-producing islets perform better than normal islets [15]. Also, cell therapy with $\mathrm{PC} 1 / 3-$ producing alpha cells improves glucose handling in $d b / d b$ mice [33].

The mechanism leading to upregulation of GLP-1 from alpha cells needs to be determined. One possibility is increased production or activity of $\mathrm{PC} 1 / 3$. Indeed it has been shown that $\mathrm{PC} 1 / 3$ is upregulated by high glucose in alpha cells [34] and in hyperglycaemic $d b / d b$ mice [17]. Therefore, it is possible that this is also the mechanism in our studies. Our data did show heterogeneity of $\mathrm{PC} 1 / 3$ production with mainly low but detectable levels in glucagon immunoreactive cells. Using two different antisera, we were able to demonstrate N-terminally biologically active GLP-1 as well as amidated GLP-1, both of which result from $\mathrm{PC} 1 / 3$ cleavage of proglucagon, providing further evidence of $\mathrm{PC} 1 / 3$ activity in alpha cells. Interestingly, fully processed GLP-1 can be detected in the plasma of humans with $\mathrm{PC} 1 / 3$ deficiency [35] and this finding emphasises that there are some aspects of proglucagon processing that are yet to be understood. As an alternative possibility there could be an inherent presence of $\mathrm{PC} 1 / 3$ in alpha cells which, during upregulation of transcription and translation of proglucagon, would lead to increased levels of GLP-1 accompanied by increased levels of circulating glucagon. In the present study, however, we did not see an increase in circulating glucagon (data not shown) accompanying the increase in GLP-1 in P. obesus.

When $P$. obesus were fed a HED the BCM increased but the insulin content of the pancreases of non-responders was significantly higher than in hyperglycaemic $P$. obesus, and so was the intensity of insulin staining, although there was no difference in BCM. The reason for this could be that $\mathrm{BCM}$ is a measure of the volume of the area of the endocrine pancreas that has any positive staining for insulin, and is not related to the quantity of insulin in the cells. If there is an expansion of the islet area with peripheral weak insulin staining, this will be reflected in an increased $\mathrm{BCM}$ but not indicative of the level of functionality. Insulin content of the pancreas and intensity of insulin immunoreactivity could be a better estimate for a functional BCM. We also saw the same level of increase of insulin in vena porta vessels from non-responders and hyperglycaemic animals compared with the LE controls, despite profound differences in $\mathrm{mBG}$ levels. This suggests that the responders are not able to compensate for elevated $\mathrm{mBG}$ by increasing insulin secretion, probably because of an inadequate functional BCM [25].

The marked inhibition by exendin (9-39) on GSIS in the isolated human islets demonstrates that the GLP-1 receptors in these islets are already active. This could be explained by constitutively active receptors [36] or by an adequate amount of GLP-1 present locally to activate the receptor. The level of active GLP-1 measured in the islet medium of $1 \mathrm{~h}$ incubations as well as the blunting of the GSIS by the GLP-1R antagonist exendin (9-39) favours the latter possibility. In addition, in similar experimental setups we failed to see the expected increment in insulin release by addition of exogenous GLP-1 (data not shown). So why is alpha cell GLP-1 production switched on in healthy human islets? There could be several reasons for this. For example, they may have experienced metabolic stress, such as hypoxia before or during the isolation procedure, shipment or subsequent culture before the experiments were undertaken. Further studies are needed to explore whether GLP-1 secretion from alpha cells in humans is a real phenomenon under normal or diabetic conditions and to what extent failure in this process could be involved in the pathogenesis of diabetes.

Acknowledgements We would like to thank L. Eriksen, H. JensenHolm, T. Rørmose Hansen, T. Merethe Olsen and S. Primdahl for technical assistance, and the National Disease Research Interchange (NDRI) for providing human pancreatic sections. We thank D. F. Steiner for providing the PC2 antibody. K. Maedler is supported by the German Research Foundation (DFG, Emmy Noether Programme MA4172/1-1).

Duality of interest The authors declare that there is no duality of interest associated with this manuscript.

\section{References}

1. Anonymous (1995) UK prospective diabetes study 16 . Overview of 6 years' therapy of type II diabetes: a progressive disease. U.K. Prospective Diabetes Study Group. Diabetes 44:1249-1258 
2. Drucker DJ (2006) The biology of incretin hormones. Cell Metab 3:153-165

3. Farilla L, Bulotta A, Hirshberg B et al (2003) Glucagon-like peptide 1 inhibits cell apoptosis and improves glucose responsiveness of freshly isolated human islets. Endocrinology 144:5149-5158

4. Bregenbolt S, Moldrup A, Blume N et al (2005) The longacting glucagon-like peptide-1 analogue, liraglutide, inhibits beta-cell apoptosis in vitro. Biochem Biophys Res Commun 330:577-584

5. Farilla L, Hui H, Bertolotto C et al (2002) Glucagon-like peptide-1 promotes islet cell growth and inhibits apoptosis in Zucker diabetic rats. Endocrinology 143:4397-4408

6. Wang Q, Brubaker PL (2002) Glucagon-like peptide-1 treatment delays the onset of diabetes in 8 week-old $\mathrm{db} / \mathrm{db}$ mice. Diabetologia 45:1263-1273

7. Perfetti R, Zhou J, Doyle ME, Egan JM (2000) Glucagon-like peptide-1 induces cell proliferation and pancreatic-duodenum homeobox-1 expression and increases endocrine cell mass in the pancreas of old, glucose-intolerant rats. Endocrinology 141:46004605

8. Rouillé Y, Martin S, Steiner DF (1995) Differential processing of proglucagon by the subtilisin-like prohormone convertases PC2 and $\mathrm{PC} 3$ to generate either glucagon or glucagon-like peptide. J Biol Chem 270:26488-26496

9. Rouillé Y, Kantengwa S, Irminger JC, Halban PA (1997) Role of the prohormone convertase $\mathrm{PC} 3$ in the processing of proglucagon to glucagon-like peptide 1. J Biol Chem 272:32810-32816

10. Vilsboll T, Agerso H, Krarup T, Holst JJ (2003) Similar elimination rates of glucagon-like peptide-1 in obese type 2 diabetic patients and healthy subjects. J Clin Endocrinol Metab 88:220-224

11. Deacon CF, Johnsen AH, Holst JJ (1995) Degradation of glucagon-like peptide-1 by human plasma in vitro yields an Nterminally truncated peptide that is a major endogenous metabolite in vivo. J Clin Endocrinol Metab 80:952-957

12. Heller RS, Aponte GW (1995) Intra-islet regulation of hormone secretion by glucagon-like peptide-1-(7-36) amide. Am J Physiol Gastrointest Liver Physiol 269:G852-G860

13. Masur K, Tibaduiza EC, Chen C, Ligon B, Beinborn M (2005) Basal receptor activation by locally produced glucagon-like peptide-1 contributes to maintaining beta cell function. Mol Endocrinol 19:1373-1382

14. Mojsov S, Kopczynski MG, Habener JF (1990) Both amidated and nonamidated forms of glucagon-like peptide I are synthesized in the rat intestine and the pancreas. J Biol Chem 265:8001-8008

15. Wideman RD, Yu ILY, Webber TD et al (2006) Improving function and survival of pancreatic islets by endogenous production of glucagon-like peptide 1 (GLP-1). Proc Natl Acad Sci USA 103:13468-13473

16. Wilson ME, Kalamaras JA, German MS (2002) Expression pattern of IAPP and prohormone convertase $1 / 3$ reveals a distinctive set of endocrine cells in the embryonic pancreas. Mech Dev 115:171-176

17. Kilimnik G, Kim A, Steiner DF, Hara M (2010) Intraislet production of GLP-1 by activation of prohormone convertase 1/ 3 in pancreatic alpha-cells in mouse models of beta-cell regeneration. Islets 2:149-155

18. Thyssen S, Arany E, Hill DJ (2006) Ontogeny of regeneration of beta-cells in the neonatal rat after treatment with streptozotocin. Endocrinology 147:2346-2356

19. Nie Y, Nakashima M, Brubaker PL et al (2000) Regulation of pancreatic PC1 and PC2 associated with increased glucagon-like peptide 1 in diabetic rats. J Clin Invest 105:955-965
20. Kalderon B, Gutman A, Levy E (1986) Characterization of stages in development of obesity-diabetes syndrome in sand rat (Psammomys obesus). Diabetes 35:717-724

21. Shafrir E, Ziv E (1998) Cellular mechanism of nutritionally induced insulin resistance: The desert rodent Psammomys obesus and other animals in which insulin resistance leads to detrimental outcome. J Basic Clin Physiol Pharmacol 9:347-385

22. Kaiser N, Yuli M, Ueckaya G et al (2005) Dynamic changes in beta-cell mass and pancreatic insulin during the evolution of nutrition-dependent diabetes in Psammomys obesus-impact of glycemic control. Diabetes 54:138-145

23. Donath MY, Gross DJ, Cerasi E, Kaiser N (1999) Hyperglycemiainduced beta-cell apoptosis in pancreatic islets of Psammomys obesus during development of diabetes. Diabetes 48:738-744

24. Kaiser N, Nesher R, Donath MY et al (2005) Psammomys obesus, a model for environment-gene interactions in type 2 diabetes. Diabetes 54:S137-S144

25. Vedtofte L, Bödarsdottir TB, Gotfredsen CF, Karlsen AE, Knudsen LB, Heller RS (2010) Liraglutide, but not vildagliptin, restores normoglycaemia and insulin content in the animal model of type 2 diabetes, Psammomys obesus. Regul Pept 160:106-114

26. Orskov C, Rabenhoj L, Wettergren A, Kofod H, Holst JJ (1994) Tissue and plasma concentrations of amidated and glycineextended glucagon-like peptide I in humans. Diabetes 43:535-539

27. Brand CL, Rolin B, Jorgensen PN, Svendsen I, Kristensen JS, Holst JJ (1994) Immunoneutralization of endogenous glucagon with monoclonal glucagon antibody normalizes hyperglycaemia in moderately streptozotocin-diabetic rats. Diabetologia 37:985-993

28. Raun K, von Voss P, Gotfredsen CF, Golozoubova V, Rolin B, Knudsen LB (2007) Liraglutide, a long-acting glucagon-like peptide-1 analog, reduces body weight and food intake in obese candy-fed rats, whereas a dipeptidyl peptidase-iv inhibitor, vildagliptin, does not. Diabetes 56:8-15

29. Gundersen HJG (2002) The smooth fractionator. J Microsc 207:191-210

30. Runge S, Wulff BS, Madsen K, Brauner-Osborne H, Knudsen LB (2003) Different domains of the glucagon and glucagon-like peptide-1 receptors provide the critical determinants of ligand selectivity. Br J Pharmacol 138:787-794

31. Martin B, Dotson CD, Shin YK et al (2009) Modulation of taste sensitivity by GLP-1 signaling in taste buds. Ann NY Acad Sci 1170:98-101

32. Bosco D, Armanet M, Morel P et al (2010) Unique arrangement of alpha and beta cells in human islets of Langerhans. Diabetes 59 (1):202-1210

33. Wideman RD, Gray SL, Covey SD, Webb GC, Kieffer TJ (2008) Transplantation of $\mathrm{PC} 1 / 3$-expressing $\alpha$ cells improves glucose handling and cold tolerance in leptin-resistant mice. Mol Ther 17:191-198

34. McGirr R, Ejbick CE, Carter DE et al (2005) Glucose dependence of the regulated secretory pathway in alpha TC1-6 cells. Endocrinology 146:4514-4523

35. Jackson RS, Creemers JWM, Farooqi IS et al (2003) Smallintestinal dysfunction accompanies the complex endocrinopathy of human proprotein convertase 1 deficiency. J Clin Invest 112:1550-1560

36. Serre V, Dolci W, Schaerer E et al (1998) Exendin-(9-39) is an inverse agonist of the murine glucagon-like peptide-1 receptor: implications for basal intracellular cyclic adenosine 3', 5'-monophosphate levels and $\beta$ cell glucose competence. Endocrinology 139:4448-4454 